\title{
British comedy in an ever-changing city
}

\section{Michael Coveney}

\section{(2) OpenEdition \\ Journals}

Electronic version

URL: http://journals.openedition.org/shakespeare/1595

DOI: 10.4000/shakespeare.1595

ISSN: 2271-6424

\section{Publisher}

Société Française Shakespeare

\section{Printed version}

Date of publication: 1 March 2011

Number of pages: $27-42$

ISBN: 2-9521475-7-4

\section{Electronic reference}

Michael Coveney, "British comedy in an ever-changing city ", Actes des congrès de la Société française Shakespeare [Online], 28 | 2011, Online since 15 February 2011, connection on 06 May 2019. URL : http://journals.openedition.org/shakespeare/1595; DOI : 10.4000/shakespeare.1595 


\section{Shakespeare et la Cité}

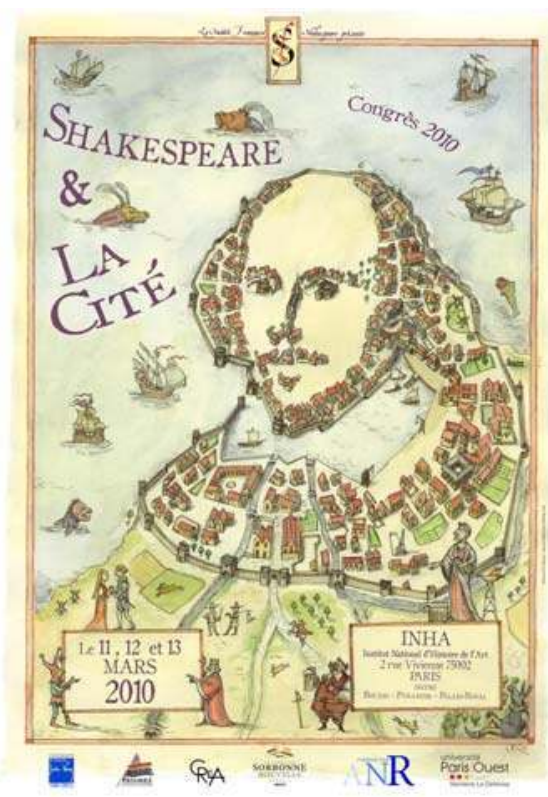

actes du Congrès

organisé par la

SOCIÉTÉ FRANÇAISE SHAKESPEARE

les 11,12 et 13 mars 10

textes réunis par

Pierre KAPITANIAK

sous la direction de

Dominique GoY-BLANQUET 
COUVERTURE :

Edouard Lekston 2010

conception graphique et logo

Pierre Kapitaniak

\section{(C) 2011 Société Française Shakespeare Institut du Monde Anglophone} Université de Paris III - Sorbonne Nouvelle 5 rue de l'École de Médecine 75006 Paris

www.societefrancaiseshakespeare.org réservés pour tous les pays 


\title{
BRITISH COMEDY IN AN EVER-CHANGING CITY
}

\author{
Michael COVENEY
}

L'idée de la cite, et de la citoyenneté, dans Shakespeare et plus abstraite et plus poétique que dans les grandes « city comedies » de Ben Jonson et de Thomas Middleton. Mais la grandeur de Shakespeare permet à des pièces comme Measure for Measure et Timon of Athens d'être refaçonnées comme de véritables " city tragedies ». Et cette vitalité et cette satire des meilleures comédies jacobéennes continuent à être très présentes dans le théâtre britannique contemporain.

The idea of the city, and citizenship, in Shakespeare is more abstract, and more poetic, than in the great city comedies of Ben Jonson and Middleton. But the greatness of Shakespeare allows for plays like Measure for Measure and Timon of Athens to be re-minted as genuine city tragedies. And there is a great and abiding strain in contemporary British drama of the vitality and satire in the best Jacobean comedy.

$\mathrm{I}$

have often wondered what Shakespeare's audiences at Julius Caesar must have felt about ancient Rome and the history of the first people to invade our island. Were their rulers like our rulers, their people like our people, their city like our city?

The most recent Royal Shakespeare Company production of the play begins with an interpolation, a bear-pit fight between two near naked sub-humans, Romulus and Remus, the victor claiming the spoils and founding the city that is then represented as a seething mob on a video film, a virtual crowd. ${ }^{1}$

This mob appears on screens as the crowd at the funeral oration and the soldiers at Philippi. Amazingly, to me at least, this filmic proletariat even takes a curtain call, bowing and waving to the real audience as if they could see us through the membrane of the celluloid.

This was doubly hilarious as the actor playing Julius Caesar had already contributed a first night howler that is instantly memorialised in Stratford folklore: as he proudly proclaimed that he was "constant as the northern star,"2 he tripped on his toga and fell on his fanny.

I am not trying to suggest that Julius Caesar is a city comedy, though of course funny things always happen in performance. When the Globe did the play some years ago, the authenticity of the funeral scene was so great, and the audience involvement so real, that one of the extras shouting out for the will to be read was asked to shut up and

\footnotetext{
${ }^{1}$ Julius Caesar, directed by Lucy Bailey at Stratford-upon-Avon, 2009.

${ }^{2}$ Julius Caesar, III.i.65 (All Shakespeare quotations from The Complete Works ed. Jonathan Bate and Eric Rasmussen, RSC/Macmillan 2007).
} 
move on by one of the officious ushers who roam the pit and make sure that no-one is standing or sitting in the wrong place. ${ }^{3}$ The poor actor protested that he was in the play - it was a modern dress production but the usher was unimpressed and insisted that he cleared the gangway and moved along.

It may be worth noting, too, that when John Gielgud played Caesar at the National Theatre in London in 1977 he was rather crestfallen to learn that the crowd would only consist of two dozen actors, recalling that there used to be hundreds, in the heyday of the late Victorian and Edwardian theatre. Today they're on film.

We still relate in Britain to the Romans much more than to their successive invaders and occupiers: in our roads, the vestigial remains of city walls in our Roman towns such as York, Colchester or Chichester, or just plain Chester, and in our language and our legal system.

And the idea of "civitas" - of civility and of being a citizen derived from the Latin, as well as the idea behind the word, informs so much of Shakespeare's comedy and, I believe, the root and branch of our contemporary theatre in Britain, too.

In Much Ado About Nothing Beatrice can joke that Claudio is as "civil as an orange" (II.i.203), referring to the bitterness of the Seville orange while Claudio stands quietly by, but civil, or civic, behaviour whether it be Othello's doing the State some service, or in the subversive paradigms of civil and authoritarian hierarchy in The Tempest or Measure for Measure - is the yardstick, the standard, the ideal, of how Shakespeare saw the way we should live.

As a country boy, Shakespeare's way of writing about the city is often one of visiting it with excitement, rather than anatomising its daily routines as writers like Ben Jonson and Thomas Middleton do, carrying their characters through the streets, shops and taverns.

When Falstaff brings Justice Shallow and the others from Gloucestershire for his triumphant entree to the court of the new King $\mathrm{Hal}$, the scene is preceded by two grooms crying for "More rushes, more rushes, the trumpets have sounded; it will be two of the clock ere they come from the coronation" (2 Henry IV, v.v.1).

And soon, of course, the Lord Chief Justice is dispatching Sir John to the Fleet prison; the golden age of carefree carousing in the

3 Julius Caesar, directed by Mark Rylance, Shakespeare's Globe, 1999. 
Eastcheap tavern is already a thing of the past and the thin-blooded Prince John sounds the note of civic propriety in the last words of the play, both harsh and curiously beautiful:

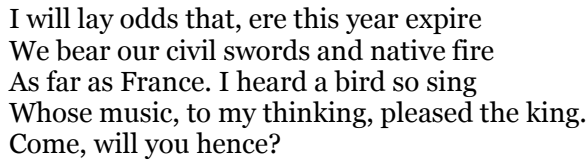

It is as though the reality of what has happened on the city streets has already expired in the smug smog of the royal purpose. Shakespeare often uses the idea of city life in a deliberately vague and unlikely way. For instance, in Twelfth Night, when Sebastian falls in love unexpectedly with the suddenly rapacious Olivia, he assumes an identity he simply doesn't have when he's a tourist, saying things like, "Shall we go see the relics of this town?" (III.iii.20) - what town? This is Illyria, lady - or "I pray you let us satisfy our eyes with the memorials and things of fame that do renown this city" (III.iii.23-25) - and, again, what city exactly, is that?

I would like to discuss two contemporary British plays in this context of citizenship in a minute, but first we should highlight the stark differences between a play like Shakespeare's Henry IV (both parts) and Ben Jonson's Everyman in His Humour. Both were first performed in 1598, the year before the Globe and James Shapiro's excellent book, and Shakespeare probably played Old Knowell, a suspicious father who pursues his son across London in the course of one day, from dawn to dusk.

The father and son relationship in both plays is the crux of the matter, but while Shakespeare sets his to the outlines of historical chronicle, and weighs the higher matters of how one should best live as a citizen and, indeed, as a king, Jonson first sets his play, as directed by convention, in Florence. By the time he writes a prologue to the 1616 Folio edition, however, he is adamant that the characters are to be English, and the setting, London.

In moving the play to London for his first real success coincidentally written in the same year as he killed an actor in a duel and was imprisoned - Jonson was deliberately aligning the piece with the city comedies of John Marston, Thomas Middleton and others 
where the metropolis itself becomes almost a character in the day-today affairs of the urban middle-class, and where the plot - one of dizzying and brilliant complexity in this play no less than in his masterpiece in the genre, Bartholomew Fair - is a vehicle for a critical display of modern moods and manners.

So, Old Knowell sets out from pastoral Hoxton in the north, crossing Moorfields to the City stews and the Windmill Tavern, following his son, Young Knowell who is a decent lad in love with Bridget, the sister of a hypochondriac, Kitely, who is consumed with jealousy. This Kitely, a close cousin of Shakespeare's Ford in The Merry Wives, which had also opened this season in the Shoreditch theatre, is convinced that his wife is whoring (she isn't) at the waterbearer's lodging - where, too, the ludicrous martial figure of Captain Bobadill (close cousin, again, of Pistol in the Henry plays) rules the roost.

Although the play was popular in David Garrick's day, and Charles Dickens acted the role of the bombastic Bobadill in an 1845 amateur production, there is record of only three revivals since: one in 1937, one by Joan Littlewood and her Theatre Workshop in 1960 and the one I'd been waiting for in the RSC's newly opened Swan Theatre in Stratford-upon-Avon in 1986. It's not just the intrigues, the deceptions, the gulling, the arguments about tobacco, the roistering, that make the play so enjoyable; it's the picture of a city on the move, on the make and on the money.

Shakespeare's Henry IV plays, and Jonson's first Everyman play, appear in the same year, too, as John Stow's important Survey of London in which the historian reckoned that London was being steadily wrecked by the population, which had grown by 120 per cent in the $16^{\text {th }}$ century -despite the plague - from 75 ,0oo people to 200,000. Stow lamented the chronic overbuilding which stemmed from the greed of developers and speculators, and he saw swindlers everywhere "that more regarded their own private gain, than the common good of the City."4

How familiar does that sound? Today, in London, we have two new plays, both playing in the West End, that are derived directly from the sort of civic disillusion and unrest we sometimes find in Shakespeare's histories (notably perhaps the Jack Cade scenes in

\footnotetext{
4 John Stow, A Survey of London (London: John Wolfe, 1598), p. 127.
} 
Henry VI), but it's easier to see a precedent for the modern city comedies of the British stage in those of Jonson, Marston and Middleton.

There is in contemporary British drama an ineluctable strain of civic satire and political purpose that is far more Jonsonian than Shakespearean. But Shakespeare is always unavoidably implicated, because of his greatness in transforming the urgent civic issues, say, of Troilus and Cressida or Measure for Measure or The Merchant of Venice, into great poetry and philosophical argument. And this strain comes from the Jacobeans right through the Restoration comedies of Congreve and Wycherley to Goldsmith and Sheridan in the $18^{\text {th }}$ century and finally (admittedly after a big hiatus) Shaw and Granville Barker at the start of the $20^{\text {th }}$.

Theatre in London is conscious of the broad lines of this development and has always viewed Shakespeare backwards through not only these precursors but also Brecht and Joan Littlewood, who was our equivalent, but much rougher, of Ariane Mnouchkine. This leads, also, to the main justification for Peter Hall founding the Royal Shakespeare Company in 1960 , in order to place our national poet in the context of a contemporary theatre. Hall always said that you should think of a classic as a modern play and a modern play as a classic. And this in turn explains why the two new plays to which I have already referred - Enron by Lucy Prebble ${ }^{5}$ and Jerusalem by Jez Butterworth ${ }^{6}$ - have made such a big impact, quite apart from their inherent and distinctive qualities.

Both plays were presented at the Royal Court Theatre, spiritual and practical home of Shaw and Granville Barker and later of John Osborne and Arnold Wesker, and both do, I believe, remind modern audiences of where our theatre comes from. In Enron, Lucy Prebble, a very young writer, has written a thrilling analysis of the collapse of America's seventh largest corporation in 2001; the success of the play has proved, for the moment at least, that there is no business like big business in show business.

Of course the meltdown in American capitalism is indivisible from that in our own, but the metaphorical power of the play, which is certainly Jacobean, catches the crazy energy and tunnel vision of what

\footnotetext{
5 Lucy Prebble, Enron (Methuen Drama, 2009).

6 Jez Butterworth, Jerusalem (Nick Hern Books, 2009).
} 
was going on in our own City institutions, and in the character of Jeffrey Skilling, the former chief executive of Enron now serving a long prison sentence, a tragic anti-hero, we have a Macbeth of market manipulation who literally creates capitalist castles in the air by inventing a truly Jonsonian scheme of criminal fantasy: he brings California to its knees with power cuts in order to sell on electricity at massively inflated prices. This really did happen.

Enron is also an echo of a scintillating verse play called Serious Money, written by Caryl Churchill7 in 1987, "hot off the presses" on the international trading floors, an exciting response to the Big Bang, concupiscence and pillage among the corporate raiders, take-over bids and make-believe world of futures and options. Churchill prefaced her play by quoting a scene of Thomas Shadwell's 1692 comedy The Volunteers: or The Stockjobbers and in this extract there is a premonitory flash of a nation on the rampage for shares in public enterprises and the leisure markets - not in hotels or fashion, but in performing monkeys and rope acts.

Poor old Shadwell is best remembered as John Dryden's pilloried tautologist in Mac Flecknoe: "The rest to some faint meaning make pretense; but Shadwell never deviates into sense." ${ }^{8}$ But his example was a direct inspiration to Churchill, whose every single character was marked by greed and corruption, from the chairman of Albion Products to the corporate raider, the Ghanaian importer and the Peruvian investor who sheds her holdings in the mines when the price of copper plummets, abandoning the work force to their fate. There's an unexplained suicide and a landslide election victory for the Conservative Party - "five more glorious years"9 - as the loads-amoney bandwagon rolls inexorably onwards.

Serious Money, like two earlier epic city comedy collaborations between David Hare and Howard Brenton - Brassneck (1973) ${ }^{10}$ about a family and its fortunes in a Britain of shady deals and drug empire connections; and Pravda (1985) ${ }^{11}$ monitoring the arrival in a listless newspaper industry of a grotesque villainous mogul and media

\footnotetext{
7 Caryl Churchill, Serious Money (Methuen, 1987).

8 John Dryden, Mac Flecknoe, in Selected Poems (Penguin Classics, 2001), p. 99.

${ }^{9}$ Slogan of the Conservative Party's election campaign in 1984.

${ }^{10}$ Howard Brenton and David Hare, Brassneck (Methuen, 1974).

${ }^{11}$ Howard Brenton and David Hare, Pravda (Methuen, 1986).
} 
magnate not at all dissimilar to an amalgamation of Rupert Murdoch and the late Robert Maxwell - operated in a mood of helpless but theatrically vibrant opposition.

Enron, on the other hand, now represents a majority feeling about what has gone on, a general outrage that has led to corrective political action, just as the Bernie Madoff ${ }^{12}$ trial in America also offered another summary of what went wrong. But of course as we know from history, and the Jacobeans, nothing ever really changes and we need these plays to keep us alert and our communal sense of civil and moral justice intact.

Butterworth's Jerusalem also has a Shakespearean character at its centre in the figure of Johnny Rooster, a Falstaffian party-giver and drug dealer who lives in a mobile home in the heart of a West Country forest on the edge of the urban encroachment, that is, a council estate, that mock memory of a vivid and meaningful street life in the city. It is the day of the local fair and the day of Johnny's eviction. It is also St George's Day (nobody mentions Shakespeare's birthday) and that local fair is in full swing, though it's not what it used to be.

The play contains a poetic farewell to the buried life of the old stone circles, the legends and mythologies of Arthurian Albion, the force of the ley lines, and also operates as their last resurrection. But Johnny, whose very existence is led in defiance of the civic authorities, will no more conquer than will Falstaff, and his fate is just as cruel. He gives some advice to his six-year-old son, who has visited the forest encampment with his mother: "School is a lie. Prison's a waste of time. Girls are wondrous. Grab your fill... Don't listen to no-one and nothing but what your own heart bids. Lie. Cheat. Steal. Fight to the death. Show me your teeth."13

This flagrant outsiderism embodied in Johnny Rooster as much as in any Lord of Misrule, works like a safety valve for our frustrated transgressive instincts, just as it does in Jacobean city comedy. You can only behave badly in the country if you're upsetting the people coming from the town, but urban hooliganism, if properly expressed, can be just as invigorating. One of the best examples is the outlandish

\footnotetext{
12 Bernard Madoff, New York stockbroker convicted in 2009 of defrauding thousands of investors of billions of dollars and sentenced to a maximum prison term of 150 years.

13 Jerusalem, Act 3 .
} 
collaboration between Jonson, John Marston and George Chapman on Eastward Ho! in 1604 (the same year as Measure for Measure).

The play is best remembered perhaps for the fact that Jonson and Chapman were thrown briefly into prison (Marston escaped) for commenting adversely on the purchase of knighthoods, authorized by King James, and also for some poor taste Scottish jokes. But the combination of a goldsmith's apprenticeship, the hilarious determination of a city daughter to become a lady, with disastrous results, an expedition to Virginia that stalls laughably on the Isle of Dogs, and a persistent undertow of licentiousness, make it irresistible to read and indeed to watch in the theatre, as the RSC proved only a few years ago.

The critical reputation of Thomas Middleton owes a great deal to T. S. Eliot, though he mysteriously ignored one of the playwright's most complex city comedies, A Chaste Maid in Cheapside (1613). The poet Swinburne said of it that it was "a play of quite exceptional freedom and audacity, and certainly one of the drollest and liveliest that ever broke the bounds of propriety or shook the sides of merriment." 14 It is a rich-veined comic masterpiece, a treasure trove of bawdy language in which one chief character, tainted with a sinister malice perhaps more characteristic of a tragic malcontent, is prime mover in a world where lust and prosperity govern moral conduct completely; he is kept as a stud in the house of an impotent aristocrat, enjoying a life of material ease in exchange for making his host's wife pregnant.

Eliot didn't overlook the earlier Middleton collaboration with Thomas Dekker, The Roaring Girl (1608), in his Elizabethan Essays, and thanks to Helen Mirren at the RSC in 1983 - long before she became famous as the Queen - we met the fantastical Moll Cutpurse, a transvestite blend of Falstaff and Cupid, a punk brawler, fixer of relationships, scallywag, tomboy, and scourge of the police. She's one of the most extraordinary city life characters in our stage history and no contemporary British dramatist has been able to match her with a modern equivalent; our gangsters and working class thugs are always male and usually dislikeable.

14 Algernon Charles Swinburne, The Age of Shakespeare (London: Chatto \& Windus, 1908), p. 161. 
But the RSC also showed that we look to these plays for a confirmation of our own civic identity in its vivid depiction of street life, mercantile activity by the river, vendors on market day and the domestic strife in two particular households where morality, as well as social status, is on the move: in the sub-plot, two merry wives (lecherously named Openwork and Gallipot) are playing off their tedious shopkeeper husbands against the gallants of the town.

Licentiousness is mainly what got the Jacobean city comedy writers into trouble. And typically, of course, Ben Jonson's defence of the theatre, unlike others', was an attack on its opponents, who were the city authorities and the puritans, and that defiance was mounted in the name of "fun." His greatest statement of this attitude is in the daddy of all city comedies, Bartholomew Fair in 1614, which is in part a skit on Marston's The Malcontent and indeed Shakespeare's Measure for Measure but which is mainly the most glorious cacophony of the sights and smells of Jacobean London that we have, on a day at Smithfield Market, or Bartholomew Fair.

Not unusually in European culture, the British have a deep nostalgia for the fairs and fiestas of their past, but we are not so good at maintaining them in the present. Our fairgrounds are tatty, our festival culture reborn in commercially led musical blow-outs like Glastonbury or genteel literary pow-wows in white middle-class market towns, or at the smoothed-out cultural bonanzas in Edinburgh and Manchester. But there are certain pockets of the city such as Camden Lock in London or the streets of Edinburgh during festival time that renew this Jonsonian atmosphere, its pungency, its dangers and its pell mell pleasure principle.

Bartholomew Fair is a play without a hero, but with many strands, all cunningly interwoven, as one party descends on the fair to enjoy themselves, another to close it down. Although our most Jacobean contemporary playwright, Howard Brenton, claimed the play as a direct example for his own day-at-the races comedy, Epsom Downs (1976), ${ }^{15}$ he came nowhere near matching Jonson's genius for ideological conflict, satirical wrath and the creation of character in a process of hilarious and inspired combustion.

Humphrey Wasp, for instance, the manservant of the Harrow gentleman, Bartholomew Cokes, is impelled almost completely by the

\footnotetext{
15 Howard Brenton, Epsom Downs (Eyre Methuen, 1977).
} 
spirit of contradiction. He participates in a foolish game of vapours which consists in opposing the last man who spoke, whoever he be, and however right. But to be right is to be wrong. "I am not," says Wasp, "in the right, nor never was in the right, nor never will be in the right, while I am in my right mind," 16 therefore proving no doubt that to be in the wrong is a symptom of sanity.

Shakespeare liked fun as much as the next man, but his view of it as a playwright was more complicated, and the nearest he comes to rivalling the city silliness of Wasp is in the expression of characters in the grip of a tragic delusion, such as Ford in Merry Wives, or Malvolio in the letter scene of Twelfth Night. In Bartholomew Fair we see the total subversion of civic order where, in the words of the Duke in Measure for Measure, "liberty plucks justice by the nose, the baby beats the nurse, and quite athwart goes all decorum" (I.iv.30-32).

Ironically, given that it's arguably the most city conscious of Shakespeare's plays, Measure for Measure was first performed at court in 1604. It's a tough play and its insistent and unsettling theme of sex in the city no doubt contributed to its unpopularity with the Victorians and its sporadic revivals in the first half of the last century. The figures of greatest authority in the play, both charged with civic responsibility, are morally corrupt: Angelo, the Duke's representative during his absence, asks Isabella to sleep with him and he will save her brother's life; the Duke, having resigned his office to leave the dirty work of clearing up the city to someone else, then turns on Isabella with the suggestion that, as he has indeed saved her brother's life, she should marry him. Isabella rebuffs Angelo, just about, but how does she react to the Duke's proposal? It's entirely down to the actress.

It was Peter Brook who reinvented the play for the modern theatre in Britain, in a famous production at Stratford-upon-Avon in 1950, with John Gielgud as Angelo; and in 1978 in Paris at the Bouffes $\mathrm{du}$ Nord, Brook re-visited the play in a completely different manner, as we shall see. Between these two versions, we can begin to see how Shakespeare's cityscape is less essential to his purpose than is the city in Ben Jonson or Middleton.

In the most recent revival in London this year, at the Almeida Theatre in Islington, the director Michael Attenborough sets the tone with a pair of skimpily clad prostitutes gyrating in doorways in the red

\footnotetext{
${ }^{16}$ Bartholomew Fair, IV.iv.61-3 (New Mermaids, 1977).
} 
light district - Lucio is their pimp as the action unfolds - and the Duke's office is dominated by a huge tapestry of the rape of the Sabine women.

This is a nod towards Brook's first approach, but cannot sustain the wild invention Brook employed to catapult the play, as one critic said, into a central position in the classic repertoire in 1950. The prison and brothel scenes were filled with stupendous visual gags - Pompey, played by a popular comedian of the day, George Rose, was at one point dragged across the stage at top speed and let down a trap at the end of a rope, and the other prisoners of the new morality were wheeled ceremoniously on, like a freak show, even down to the veteran wild Half-can "that stabbed pots" (Measure for Measure, Iv.iii.11), characters that usually only exist in Pompey's litany of them.

In The Empty Space, Brook wrote of "a base world [...] the disgusting, stinking world of medieval Vienna [...]. We must animate all this stretch of the play as the roughest comedy we can make. [...] the rough is in prose, the rest in the verse [...] If we iron Shakespeare into any one typography of theatre we lose the real meaning of the play." ${ }^{17}$

And yet, when it comes to the Bouffes production, that is precisely, it could be argued, what happened. There was a sense, the critic Irving Wardle observed, in which Brook really had aimed for a perfect consistency between the life-and-death drama and the low comedy, so that the old question of how to classify the work simply didn't arise. Wardle even went so far as to suggest that the play was now designed for a Paris audience in order to convince them that Shakespeare really could write like Racine.

There is more of the Jacobean London Shakespeare knew - in courtroom, prison, nunnery and brothel - than in any other of his plays and yet, curiously enough, you would not really know that from either version. The first Brook approach, attempted by Attenborough and taken even further by Nicholas Hytner in a neon-lit and relentlessly sour RSC revival, still leaves you contemplating not $17^{\text {th }}$ century London, not even the Viennese stews, but some poeticized simulacrum, partly because Shakespeare never insists on topographical detail or local colour, but mainly because his characters on both sides of the law transcend their own archetypes. Barnadine, the prisoner who

17 Peter Brook, The Empty Space (Penguin, 1968), p. 88, as quoted in Albert Hunt and Geoffrey Reeves, Peter Brook (Cambridge, C.U.P., 1995), p. 221. 
refuses to wake up and be executed, is not a human scrap of localised riff raff as he would be in Jonson, but a richly humanized and endearing, philosophically expressed creation.

Where Shakespeare's street scenes come alive is not in their hustle and bustle, as in Jonson, but in the intensity of the crisis played out in public. These moments are never about buying or selling, or hawking or gulling, but about life and death, even in The Comedy of Errors as well as in Cymbeline, in Twelfth Night as well as in Henry IV or Measure for Measure. In the great final scene of Measure, the actress playing Isabella was instructed by Brook in 1950 to hold a pause on "Look, if it please you, on this man condemn'd" (v.i.463) while pleading for Angelo's life until the audience could bear it no longer.

Sometimes this pause went on for two minutes. At the Bouffes, the actress held on for a bit, but not all that long, and there was no sense of public suspense because the performance had levelled out the landscape as one of being defined by the characters who stood there in relation to each other. You couldn't really make out why Brook had returned to the play. He was much more convincing in his first production at the Bouffes in 1974, which was of Timon of Athens.

At that time, Timon struck Brook as a play of the moment in dealing with money and inflation. The oil prices were in turmoil and certainly in Britain we were in the midst of a recession the like of which we have never experienced; well, not until very recently. But Brook was no more specific about the kind of city Athens was than was Shakespeare himself although he did volunteer the idea that it strangely resembled the Athens under the colonels, a town of corruption. "But that's by chance," he said. "Timon's Athens is finally as symbolic as Ubu's Poland, it could be anywhere."

"Moreover," he continued, "the protagonists behave like Greeks, Romans, Londoners. At that time make-believe was natural: in religious painting you can see in Holland a Christ confronted with a Burgomeister and, in Italy, the good citizens of Venice. That's not anachronism. It's what you would call the naïve imagination."18

Nothing about Brook's production was fixed in time, place or style. One of Brook's collaborators said that the young Timon of the

18 Programme note by Peter Brook for Timon of Athens at the Bouffes du Nord, Paris, in 1974 . 
early scenes, a rich young prodigal, barely past his adolescence, dispensing wealth with abandon, conjured everyone's memory of Gérard Philipe. Until he was betrayed he was superlatively sunny, and then his smile became a snarl and by the last act he was bellowing with unforgiving rage. "The money he found in the fourth act was not coin but gold dust which he blew out of his hand at all who came to visit him." 19

It is true that Timon is a moral fable on the waste and crime of living beyond one's means. Whereas Lucy Prebble's Enron is a play about city practices of making money, and the Jacobeans mostly concentrate on the sordid comicality of materialism in the city, Shakespeare in Timon counts the cost of buying flattery and friendship as an urban sponsor.

It's the only Shakespeare play mentioned by Marx, and it's arguably as great a city play as Measure, with the added Shakespearean ingredient of renunciation of city life in exchange for the brutal honesty of the countryside, a cynical re-tread of the dynamic in As You Like It. Marx saw the acquisition of the power of money as the instrument of universal division, which in a capitalist society would become a godlike force alienating man from his fellows but also from himself as a social animal.

Brook read this very much as a universal fable, which is surely correct, but the other approach to the play, one which pins it down with a cultural specificity, is likely in the modern theatre to make a more pressing claim on an audience's attention. Paul Scofield was magnificent in the title role for the RSC at Stratford-upon-Avon in 1965, but the production by John Schlesinger, which lacked the beautiful intensity of Brook's, boiled down to a study in eccentricity in a social void, while a later 1981 revival featured a lot of Japanese feasting scenes and a lot of slapstick around Timon's cave in the woods, a cave which might have been hired from the American television cartoon characters Fred and Wilma Flintstone.

Someone at some stage surely had to do the modern mercantile Timon of Athens that related first to the "greed is good" society of the 1980s. That someone in London at least was Trevor Nunn, who did one of his brilliant, novelistic animations similar to his RSC revivals of All's Well That Ends Well (set at the time of the Crimean War) and Othello

${ }^{19}$ Albert Hunt and Geoffrey Reeves, op. cit., p. 219. 
with Ian McKellen as a brutally buttoned up $19^{\text {th }}$ century Iago swilling brandy in great glass bulbs.

These productions reflected, as did Nunn's Timon of Athens at the Young Vic in 1991, the view of the American scholar Gary Taylor that Shakespeare plays can be reinvented as contests between social groups rather than conflicts of character. You can see how this might apply even to King Lear, performed in the same year as Timon, but infinitely bleaker and more mythological, even though everything that happens does so because of the simple misinterpretation of duty, the quest for power, the breakdown of communication. In Nunn's Timon, the strange, difficult scene of Alcibiades' banishment leaped to life as a study in political impasse; the senator seated at a green baize table was not just banishing the old captain, but seizing civic power for himself.

In Timon, there's hardly any love, and no love lost. Money, which Marx said was both the visible deity and the universal whore, distorts our view of what is important in life and turns all relationships into commercial exchanges. Timon has no family or lover, not even a blood relation. The only women are prostitutes. Timon's a civic benefactor who throws parties. Just as the cynic Apemantus is the only professional philosopher in Shakespeare, so Timon is the only professional sponsor.

There are similarities with Coriolanus (written two years later) in the soldier figure of Alcibiades, who marches against the city that has mistreated him. And like Volumnia in that play, Timon is called upon to be a conciliator. His method of doing so, indirectly, is to commit suicide, symbolically removing hatred from the city and allowing Alcibiades to make peace with the State. Of course, it is significant that the home Timon leaves and excoriates is the city of Athens, birthplace of democracy, philosophy and theatre, the very city epitome of culture.

But Trevor Nunn placed us unequivocally in London, with tramps on a London pavement outside the Savoy Hotel immediately underlining the new visibility of poverty on our city streets, the gulf in economic status and fortune between people on either side of one revolving door. Here a woolly-hatted Apemantus wandered among the dinner-suited fat cats and sycophants. The show then started with a modern street scene of artisans jostling in a celebrity culture framework of journalists and microphones where the god of "traffic" 
became one of "trade" and suddenly, for no apparent reason - a man was gunned down by the military.

The Jonsonian scenes of turncoat rejection in which three hitherto favoured creditors spurn Timon's emissaries, were set consecutively in a computerized office, a race course enclosure, specifically at Ascot, and the locker room of a squash court. The party scene with its masque of Cupid and the Amazons became a Rotary Club stag night, with gorgeous girls from the escort agency bumping and grinding to a flattened-out rap version of the Beatles' song "Money." Timon's cave was a beaten up van on a rubble heap and the hero shot himself in the head with a revolver.

The whole thing looked like a David Hare play and gave a local habitation and a name to the more generalized and somewhat more mysterious world in which the play perhaps really exists. Some critics felt that Shakespeare's general assault on ingratitude was distorted in this specific attack on mercantile values in which friendship was determined by credit-worthiness. But in redefining the play in the world of a particular production, the director allows the audience to make the connections in both, and run both versions simultaneously. It's like Love's Labour's Lost, really, another play that always thrives when firmly re-imagined in a particular setting.

But there's always a problem in pinning Shakespeare down. It's as if the contradictions in the mundane information of place and time are made as a deliberate warning against doing so. Again, there's a mythic grandeur about the death of Timon, who departs to make "his everlasting mansion upon the beached verge of the salt flood" (v.i.223224), that a grubby suicide on a rubbish dump rather undermines.

For that real sense of a city on the make and on the move we must rely on Ben Jonson and the Jacobeans, not Shakespeare. But still there is always something in every Shakespeare play that pulls us sharply back towards a sense of the time and place in which it was first performed. Today, I think we can appreciate the fact that many of the plays were performed in the open air by going to the new Shakespeare Globe on the South Bank. But it's not an authentic experience of Shakespeare's city, any more than looking at the remains of the Rose preserved under glass on the side of Southwark Bridge really transmits any kind of appreciation similar to that you can experience at Epidauros of how the Ancient Greek theatre worked. 
There's a tiny scene at the start of the fifth act of Bartholomew Fair in which Leatherhead, the hobby-horse seller, disguised as a puppet-master, is setting up the puppet show that prosecutes the comic denouement on this harum scarum fair day. In its language and its vivacity it contains everything I love about Jonson; and the whole play is like it. You get glints of the great seething city in Shakespeare, but nothing that comes off the page, and off every single page, like this:

LEATHERHEAD. Well, luck and Saint Bartholomew! Out with the sign of our invention, in the name of Wit, and do you beat the drum the while. All the foul i'the Fair, I mean all the dirt in Smithfield - that's one of Master Littlewit's carwhitchets now - will be thrown at our banner today, if the matter does not please the people. $O$ the motions that I, Lantern Leatherhead, have given light to, I' my time, since my Master Pod died! Jerusalem was a stately thing, and so was Nineveh, and The City of Norwich, and Sodom and Gomorrah, with the rising o' the prentices, and pulling down the bawdy-houses there, upon Shrove Tuesday; but the Gunpowder Plot, there was a get-penny! I have presented that to an eighteen-, or twenty-pence audience, nine times in an afternoon. Your home-born projects ever prove the best, they are so easy, and familiar. They put too much learning i'their things nowadays; and that, I fear, will be the spoil o'this. Littlewit? I say, Micklewit! If not too mickle! Look to your gathering there, Goodman Filcher.

FILCHER. I warrant you, sir.

LEATHERHEAD. And there come any gentlefolks, take twopence a piece, Sharkwell.

SHARKWELL. I warrant you sir; threepence an we can...

(v.i.1-22)

Michael COVENEY 